https://helda.helsinki.fi

\title{
Ikoma Nominal Tone
}

\author{
Aunio, Lotta
}

2010

Aunio , L 2010 , ' Ikoma Nominal Tone ' , Africana Linguistica , vol. XVI , pp. 3-30 . https://doi.org/10.3406/aflin.2010

http://hdl.handle.net/10138/42402

https://doi.org/10.3406/aflin.2010.986

submittedVersion

Downloaded from Helda, University of Helsinki institutional repository.

This is an electronic reprint of the original article.

This reprint may differ from the original in pagination and typographic detail.

Please cite the original version. 


\title{
Ikoma Nominal Tone
}

\section{Lotta Aunio}

\begin{abstract}
Ikoma is a Lacustrine Bantu language spoken in the Serengeti District, Mara Region (Western Tanzania), and classified a E(J)45 in the updated Guthrie's list. Ikoma has both lexical and grammatical tone, but lexical tonal contrasts are found only in nominal constructions. These constructions and the relevant tonal rules are discussed in this article, and it will be shown that the tone system of Ikoma nouns is more complex than the typical reduced tonal systems of other Lacustrine Bantu languages.
\end{abstract}

Keywords : Bantu languages, tone, Ikoma, Tanzania, Zone J 


\section{Introduction}

Ikoma is a Lacustrine Bantu language spoken in the Serengeti District, Mara Region (Western Tanzania) by approximately 19,000 speakers (Muzale \& Rugemalira 2008). It is classified as E(J)45 in the updated Guthrie's list (Maho 2003). In Ikoma, the language name is Egiikoma. Ikoma is closely related to Nata and Isenye, which are listed under the same code with Ikoma by Maho. All three variations are mutually intelligible, at least to some extent. There is no comprehensive tonal description of Ikoma (nor of Nata or Isenye). ${ }^{1}$

In this paper I will give a preliminary analysis of the Ikoma nominal tone system. I will present the tone classes found in Ikoma nouns, as well as tonal changes that occur with classes 1a and 2a. After the section on Penultimate Spread and Downstep, I describe the tonal rules operating in associative constructions. The last section of the paper deals with high tone insertions. In certain contexts, the nominal tone also spreads to following verbs, but this is not dealt with in this paper.

Like many other Bantu languages, Ikoma has a privative tone system (Hyman 2001). In this system, only high tones interact with each other and play any role in tonal rules. Although on the surface $\mathrm{H}$ (igh) and L(ow) are contrasted, the underlying contrast is between $\mathrm{H}$ and $\varnothing$. Thus, in this paper only high tones are marked, either with a letter $\mathrm{H}$ (in rules and derivations) or as an acute accent on the vowel that carries the high tone.

Ikoma verb stems have lost the tonal contrast, and they all behave tonally in the same manner. This is also found in other Bantu languages of the Mara region, for example in Kuria (Cammenga 2004), Ngoreme (SIL 2009c), and Zanaki (SIL 2009d).

In addition to lexical tone on nouns, Ikoma has grammatical tone that is used to differentiate certain verb forms, for example past and anterior forms, as in (1). These systems of grammatical tone without tonal contrast of verb roots are often called predictable tone systems (Odden 1989).

mbeemíri chambúsúró
n-ba-V-em-iri cham-búsúró2
VI-2.SBJ-PST-Sow-ANT 10 -seed
'they sowed seeds'

mbeemiri chambúsúró
n-ba-em-iri cham-búsúró
VI-2.SBJ-Sow-ANT 10 -seed
'they have sowed seeds'

Ikoma has a seven-vowel system with both contrastive and conditioned vowel length. Long vowels are restricted to word medial position. Conditioned long vowels result from compensatory lengthening, either when ' $u$ ' is glided to ' $w$ ', as in example (4) below, or before a prenasalized consonant, as in example (3) below.

The tone-bearing unit is the syllable, i.e. each syllable can carry at most one $\mathrm{H}$ tone and thus there are no underlying falling or rising tones. Also, bimoraic and monomoraic syllables both show only two tonal contrasts (see examples (7) to (10) below). ${ }^{3}$ However, there are surface rising and falling tones which either occur in predictable contexts or are in free variation with a level high tone.

1. References to Nata and Isenye data in this paper are based on the field notes of the author. 2. V stands for an unspecified vowel.

3. In tonal rules, syllables function as one entity, regardless of the length of the vowel, see examples (43) and (44) below. The same applies to tonal rules of the grammatical tone. 
Surface falling tones are formed in noun stems when a single $\mathrm{H}$ is associated to a long vowel. The long vowel may be either lexically long, as in example (2), or a result of compensatory vowel lengthening, as in (3). ${ }^{4}$ Long vowels caused by compensatory lengthening are phonetically shorter than lexical long vowels (SIL 2009 b). In both instances, the falling tone is in free variation with a level high tone.

\begin{tabular}{|c|c|c|c|}
\hline a-shishíita & $\sim$ & a-shishííta & 'toothbrush's \\
\hline oru-béere & $\sim$ & oru-béére & 'millet' \\
\hline gu-sáafiri & $\sim$ & gu-sááfiri & 'to travel' \\
\hline ku-ráagera & $\sim$ & ku-ráágera & 'to eat' \\
\hline omo-góondo & $\sim$ & omo-góóndo & 'field' ${ }^{\prime}$ \\
\hline ege-túumbe & $\sim$ & ege-túúmbe & 'chair' \\
\hline
\end{tabular}

Rising tones surface in vowel-initial noun stems with a high tone in stem-initial position, alternating with a level high tone, as in (4). ${ }^{7}$ A surface rising tone is also found in the class 2 a prefix baá-, the only class prefix that carries a high tone, as in (5). Again, these can also be realised as level high tones, in free variation.

\begin{tabular}{|c|c|c|c|}
\hline $\begin{array}{l}\text { omw-aátani } \\
\text { om-oóna }\end{array}$ & & $\begin{array}{l}\text { omw-áátani } \\
\text { om-óóna }\end{array}$ & $\begin{array}{l}\text { 'neighbour' } \\
\text { ‘child' }\end{array}$ \\
\hline & & báá-nyawambu & 'chameleons' \\
\hline aá & & báá-magemá & 'eagle' \\
\hline
\end{tabular}

Syllabic nasals only occur in free variation with the corresponding NV sequence. The vowel of the sequence is sometimes omitted in normal speech and thus the nasal becomes a tone bearing unit, as in (6).

4. Compensatory vowel lengthening results from the following prenasalized consonant in example (3) and from gliding of vowel ' $\mathbf{u}$ ' in example (4).

5. Most of Ikoma noun class prefixes consist of a preprefix vowel and a CV prefix (e.g. oru-). Class 9 prefix consists of only the preprefix vowel a-, and classes $2 \mathrm{a}$ and 10 prefixes do not have a preprefix (i.e. baá- and cha-, respectively). Class 1a is prefixless. Class 5 prefix erioften occurs without the preprefix when not phrase-initial, i.e. as only ri- (as in example (79) below). Noun class prefixes are subject to Dahl's Law, i.e. voicing of the prefix consonant before a voiceless stem consonant (cf. ku- $\sim$ gu- in example (2)), and to vowel harmony.

6. Since compensatory lengthening is not marked in the current orthography proposal (SIL 2009) it is not marked elsewhere in this paper.

7. This is clearly different from Ha (J66), for instance, in which TBU is the mora and there is a contrast between the high tone being associated to the first mora of the long vowel and to the second mora of the long vowel, resulting in either a rising or a falling tone on the long vowel. These are not in free variation with level high tones (Harjula 2004: 45) In Ikoma, when a long vowel with a high tone is preceded by another high tone of, for example, the associative (see section 'Associative Construction' below for further details) the tone of the long vowel is realized as falling even in stem-initial position, as in ogo-goro kó !móona 'leg of a child'. 
(6)
aramóseta
araḿseta
a-ra-mo-set-a
1.SBJ-CONT-1.OBJ-follow-FV
'he followed him'

\section{Bisyllabic and Monosyllabic Noun Stems}

Tonal distinctions are made use of in the nominal system of Ikoma. Ikoma bisyllabic noun stems represent the most common reduction of tonal contrast where the ProtoBantu contrast between HL and HH is neutralised (Philippson 1998: 316). The three underlying stem tone patterns of bisyllabic nouns are thus toneless, $\mathrm{H}$ on penultimate syllable, and $\mathrm{H}$ on final syllable, as illustrated in (7) to (9). Tonal minimal pairs are not common but do exist (10). The nominal prefixes are toneless (see section 'Tonal Changes in Classes 1a/2a' below for an exception).

(7)

$$
\begin{array}{ll}
\text { toneless: } & \\
\text { ogo-goro } & \text { 'leg' } \\
\text { omo-sisi } & \text { 'tamarind tree' } \\
\text { an-chera } & \text { 'path' } \\
\text { eri-gano } & \text { 'story' }
\end{array}
$$

(8) H on penultimate syllable:

$\begin{array}{ll}\text { oku-bóks } & \text { 'arm' } \\ \text { omu-témi } & \text { 'king' } \\ \text { omo-kéra } & \text { 'tail' } \\ \text { a-séยse } & \text { 'dog' }\end{array}$

(9) H on final syllable:

$\begin{array}{ll}\text { eki-barí } & \text { 'flower' } \\ \text { obu-kaanú } & \text { 'sesame seed' } \\ \text { a-suná } & \text { 'mosquito' } \\ \text { a-həotó } & \text { 'heron' }\end{array}$

$\begin{array}{ll}\text { omu-géndi 'traveller' } & \text { omu-gendí 'companion' } \\ \text { a-mémbe 'bell' } & \text { a-membé 'crust' }\end{array}$

Although Ikoma bisyllabic tonal types have undergone the reduction of contrast between Proto-Bantu HL and HH, Ikoma bisyllabic noun stems do not correspond to all of the reconstructed tonal patterns of Proto-Bantu. It seems that the LL pattern of the proto-language corresponds to the Ikoma toneless stems. But the Ikoma

8. There are no toneless bisyllabic stems with a long stem vowel in the database. With 3 -syllabic stems there are some toneless stems with a long vowel, but these are all class 1a nouns (see section 'Tonal Changes in Classes 1a/2a' below). This could be an accidental gap in the data, but there could also be a connection between the long vowels and stem tones. The database consists of approximately 500 tone marked noun stems. 
pattern with $\mathrm{H}$ on the penultimate syllable encompasses all three Proto-Bantu tonal patterns with a H, i.e. HL, LH, and HH. These are illustrated in (11). Thus the Ikoma pattern with $\mathrm{H}$ on final syllable seems to be a later invention. Taking this distribution into account, it is not surprising that the penultimate $\mathrm{H}$ pattern is by far the most common tonal pattern for bisyllabic nouns (covers over $65 \%$ of the bisyllabic nouns in the database).

$\begin{array}{ll}\text { an-kóks } & \text { 'chicken' } \\ \text { eri-ráka } & \text { 'voice' } \\ \text { ma-gúta } & \text { 'oil' } \\ \text { oro-réme } & \text { 'tongue' } \\ \text { obu-bére } & \text { 'millet' } \\ \text { am-bógo } & \text { 'buffalo' } \\ \text { ogo-goro } & \text { 'leg' } \\ \text { eki-nyəni } & \text { 'bird' }\end{array}$

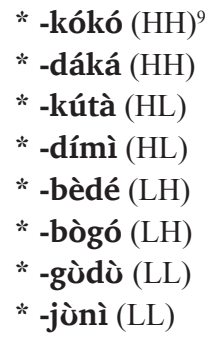

Ikoma lexical tone patterns show some free variation in surface realizations. In prepausal position, it is typical to have a rising pitch at the end of the utterance. This means that, for example, the nouns without lexical tone often have high pitch on the last syllable and thus in prepausal position they cannot necessarily be told apart from the nouns with a final $\mathrm{H}$. The stems with the penultimate $\mathrm{H}$ can have a surface high on the final syllable in prepausal position. In these, the pitch of the final syllable is either at the same level with the previous syllable or even higher. On the other hand, the penultimate syllable is sometimes prominent in prepausal position, resulting at, for example, the stems with the final $\mathrm{H}$ having the highest pitch on the penultimate syllable and not on the final syllable where the lexical tone is. These variations in surface tones, all optional, are exemplified in table (12) below.

\begin{tabular}{|l|l|l|l|}
\hline$(12)$ & & Lexical tones & Prepausal position \\
\hline & no tone & ogo-goro & ogo-goro or ogo-goró \\
\hline & penultimate H & oku-bóks & oku-bókə or oku-bókś \\
\hline & final H & eki-barí & eki-barí or eki-bári \\
\hline
\end{tabular}

Monosyllabic noun stems represent two underlying tonal patterns, namely stems with a high tone and toneless stems, as illustrated in (13) and (14). Monosyllabic noun stems only have short vowels, since word-final long vowels are not allowed in Ikoma. The tonal patterns of monosyllabic nouns seem to correspond to those of the reconstructed Proto-Bantu.

9. References for Proto-Bantu forms are from Bantu Lexical Reconstructions 3 (BLR 3, www.metafro.be/blr). 
(13) toneless stems:

$\begin{array}{ll}\text { an-da } & \text { 'stomach' ("-dà) } \\ \text { a-ka } & \text { 'lion' } \\ \text { omu-ti } & \text { 'medicine' } \\ \text { an-gwe } & \text { 'leopard' } \\ \text { omo-rya } & \text { 'root' }\end{array}$

(14) H toned stems:

$\begin{array}{ll}\text { an-dá } & \text { 'louse' ("-dá) } \\ \text { a-ká } & \text { 'home' } \\ \text { omu-tí } & \text { 'tree' ("-tí) } \\ \text { omo-bya } & \text { 'arrow' } \\ \text { am-bwe } & \text { 'jackal' }\end{array}$

\section{Multisyllabic Noun Stems}

As presented above, Ikoma mono- and bisyllabic noun stems fit the pattern of a reduced tonal system (Philippson 1998). In this system, there is at most one high tone per stem, but the place of the tone needs to be defined lexically. However, 3 -syllabic noun stems show that the Ikoma nominal tone system is indeed a bit more complex. In addition to the four logical possibilities of a reduced tonal system, namely toneless stems and a high tone on one of the syllables, in Ikoma there is a fifth pattern with a high tone multiply linked to every syllable of the noun stem. This pattern is called the 'all H' pattern here since the $\mathrm{H}$ is underlyingly associated with more than one tone-bearing unit. Thus all lexical tones are either associated to a single syllable or to the whole stem.

(15) toneless stems:

$\begin{array}{ll}\text { a-bugusi } & \text { 'upper arm' } \\ \text { a-tarari } & \text { 'valley' } \\ \text { omu-terebi } & \text { 'ladle' } \\ \text { a-sugara } & \text { 'tradition' }\end{array}$

(16) H on final syllable:

$\begin{array}{ll}\text { eke-hureró } & \text { 'metal pot' } \\ \text { omu-kandará } & \text { 'fishing line' } \\ \text { omo-sokaan } & \text { 'compromise' } \\ \text { eki-iriirí } & \text { 'shadow' }\end{array}$

(17) H on penultimate syllable:

$\begin{array}{ll}\text { a-nyagára } & \text { 'lizard' } \\ \text { eri-hundúgu } & \text { 'corpse' } \\ \text { a-shishíita } & \text { 'toothbrush' } \\ \text { a-kooróoto } & \text { 'hoof' }\end{array}$


H on prepenultimate syllable:

$\begin{array}{ll}\text { ege-tíngiro } & \text { 'heel' } \\ \text { egi-táaməoni } & \text { 'scorpion' } \\ \text { a-shánani } & \text { 'cricket' } \\ \text { ege-súruura } & \text { 'a kind of tree' }\end{array}$

(19) all H pattern:

$\begin{array}{ll}\text { eri-búrúngé } & \text { 'egg' } \\ \text { a-mátóónyí } & \text { 'vulture' } \\ \text { am-búsúrú } & \text { 'seed' } \\ \text { eri-bóónóónó } & \text { 'lump' }\end{array}$

The surface realizations of these tonal patterns show the same kind of alternations on the surface realisations as the bisyllabic noun stems. These are illustrated in table (20) below. The final syllable of the 'all H' stems can also be realised with low pitch. The 'all H' pattern is easily confused with both the pattern with the prepenultimate $\mathrm{H}$ and the pattern with the penultimate $\mathrm{H}$ even by native speakers. In both the 'all $\mathrm{H}^{\prime}$ pattern and the pattern with the prepenultimate $\mathrm{H}$, the pitch raises directly after the noun class prefix. In the pattern with the penultimate $\mathrm{H}$ as well as often in the 'all H' pattern the pitch is lowered after the penultimate syllable. However, when the nouns are not in utterance final position the differences become more evident.

\begin{tabular}{|l|l|l|}
\hline & Lexical tone & Prepausal position \\
\hline no tone & a-bugusi & a-bugusi or a-bugusí \\
\hline final H & eke-hureró & eke-hureró or eke-huréro \\
\hline penultimate H & a-nyagára & a-nyagára or a-nyagárá \\
\hline prepenultimate H & ege-tíngiro & ege-tíngiro or ege-tíngiró \\
\hline all H & eri-búrúngé & eri-búrúngé or eri-búrúnge \\
\hline
\end{tabular}

Although there are only a handful of 4-syllabic noun stems in the database, ${ }^{10}$ the data available seems to confirm the analysis: the tonal grouping follows the same pattern as with trisyllabic noun stems. Thus, the tonal melodies of the 4-syllabic noun stems form six tone groups: toneless stems, stems with a single $\mathrm{H}$ on one of the syllables, and the 'all H' pattern. These are exemplified in (21).

$\begin{array}{lll}\text { no tone: } & \text { gurumeeti } & \text { 'kind of sickness' } \\ \text { final H: } & \text { nyamagoró } & \text { 'caterpillar' } \\ \text { penultimate H: } & \text { kawaráre } & \text { 'red pepper' } \\ \text { prepenultimate H: } & \text { a-sagárami } & \text { 'kind of tree' } \\ \text { initial H: } & \begin{array}{l}\text { omw-íkorongo } \\ \text { all H: }\end{array} & \text { 'waterfall' } \\ \end{array}$

10. Nouns with four (or more) syllables are rather rare, and it is possible that at least some of these nouns are the result of compounding. All the 4-syllabic stems with the 'all H' pattern found so far are reduplicated stems. Also, quite a few of the 4-syllabic noun stems belong to noun class 1a, which has no noun class prefix. 
With 3- and 4-syllabic nouns the H-initial pattern covers $22 \%$ and $34 \%$ of the noun stems, respectively. The figures for the 'all $\mathrm{H}$ ' pattern are $42 \%$ and $31 \%$. These two patterns together form approximately the same proportion of the noun stems as the penultimate $\mathrm{H}$ pattern with bisyllabic nouns, namely $64 \%$ for the 3 -syllabic nouns and $64 \%$ for the 4 -syllabic nouns. Although the sample is not big enough for drawing definite conclusions from the distributions, it is certainly possible that the $\mathrm{H}$ initial pattern and the 'all $\mathrm{H}$ ' pattern are both presented in the penultimate $\mathrm{H}$ pattern of the bisyllabic noun stems (cf. the rule for spreading of the penultimate $\mathrm{H}$ below).

\section{Tonal Changes in Classes $1 \mathrm{a} / 2 \mathrm{a}$}

Class 1a consists, as is typical for Bantu languages, of nouns denoting relatives, some insects, reptiles, and birds as well a variety of other words. These nouns do not have a class prefix at all. In plural, these nouns are marked with the class $2 \mathrm{a}$ prefix baá-, which exceptionally has a long vowel and carries a high tone. ${ }^{11}$ The tone is most often realized as a rising tone on the long vowel (cf. example (5) above). Most of the noun stems in classes $1 \mathrm{a} / 2 \mathrm{a}$ have at least three syllables, and very few have any other tonal pattern except the toneless pattern, as in (22), or the pattern with the final $\mathrm{H}$ or penultimate $\mathrm{H}$ when there are at least 4 syllables in the stem, as in (23).

$$
\begin{aligned}
& \text { nyawambu - baá-nyawambu 'chameleon' } \\
& \text { nyaamu - baá-nyaamu 'cat' } \\
& \text { segenke - baá-segenke 'arrowhead' } \\
& \text { baamuku - baá-baamuku 'brother-in-law' } \\
& \text { maame - baá-maame 'mother's brother' } \\
& \text { magemá - baá-magemá eagle' } \\
& \text { kamaatí - baá-kamaatí 'sister-in-law' } \\
& \text { nyahumé - baá-nyahumé 'owl' } \\
& \text { kawaráre - baá-kawaráre 'red pepper' } \\
& \text { nyamagoró - baá-nyamagoró 'caterpillar' }
\end{aligned}
$$

In classes $1 \mathrm{a} / 2 \mathrm{a}$ there are some stem tone changes. Compare the citation forms of nouns 'chameleon', 'brother-in-law', and 'mother's brother' in example (22) above to the forms in example (24): the stem tone, if on the first or on the second syllable of the stem, is not realized when the noun is utterance-initial, but appears on the surface when preceded by another word. ${ }^{12}$ Thus it seems that the assumed high frequency of toneless stems in class 1a is partly due to tonal changes of the stem. This variation occurs with all class 1a nouns with a tone on the stem-initial syllable, but with only some of the class 1a nouns that have the lexical tone on the second

11. There are also other Bantu languages where class 2 a prefix is the only noun class prefix that carries a tone, see e.g. Doke \& Mofokeng (1957:40) on Southern Sotho.

12. What most often precedes a noun in Ikoma is a verb, as in example (24), but it seems that the same variation takes place when preceded by any word, e.g. Taata ichó ... and Ichó táata ... 'Yesterday father ...'. 
syllable of the stem. The data is too scarce here for making any generalizations about this variation.

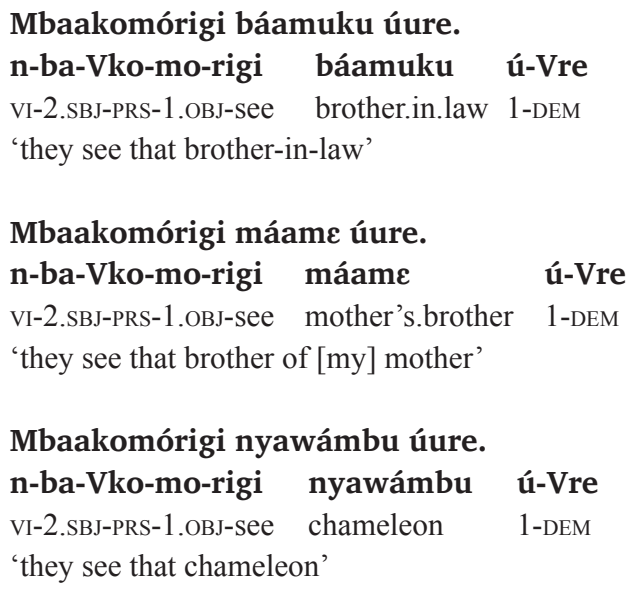

In another stem tone change, the stem tone is deleted when the noun is in plural (i.e. with class 2 a prefix baá-) and the tone is lexically associated with the first syllable of the stem, as in (25), or with the second syllable of the noun stem, as in (26) and (27). If there are two or more syllables between the prefix and the stem tone, the tone is retained, as in example (23) above.

Mbaakobárigi baábaamuku báare.
n-ba-Vko-ba-rigi baá-báamuku bá-Vre
VI-2.SBJ-PRS-2.oBJ-see 2-brother.in.law
'they see those brothers-in-law'

Mbaakobárigi baámaame báare. n-ba-Vko-ba-rigi baá-máame bá-Vre VI-2.SBJ-PRS-2.oBJ-see 2-mother's.brother 2-DEM 'they see those brothers of [my] mother'

$$
\begin{aligned}
& \text { nəorá - baá-nэวra 'agama lizard' } \\
& \text { yimá - baá-yima 'mother' } \\
& \text { murámu - baá-muramu 'sister-in-law' } \\
& \text { isśvyaara - b-iís’vyaara 'father-in-law' }
\end{aligned}
$$

(27) Mbaakobárigi baányawambu báare.

$\begin{array}{ll}\text { n-ba-Vko-ba-rigi baá-nyawámbu bá-Vre } \\ \text { VI-2.SBJ-PRS-2.OBJ-see } & \text { 2-chameleon } \\ \text { 'they see those chameleons' } & \text { 2-DEM }\end{array}$

The deletion of the $\mathrm{H}$ of the first stem syllable can be accounted for as a case of Meeussen's Rule: deleting the latter of the adjacent high tones and thus repairing the 
violation of the Obligatory Contour Principle (OCP) (Philippson 1998: 318). This is formulated and illustrated in (28) and (29). In Ikoma, this is the only instance where Meeussen's Rule has been found to be active so far. ${ }^{13}$

(28) Meeussen's Rule<smiles></smiles>

(29) Derivation

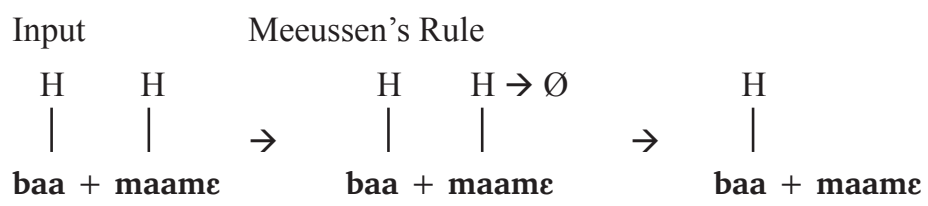

The stem high tone is deleted when there is one toneless syllable between the high tones in order to avoid the $\mathrm{H} Ø \mathrm{H}$ sequence - a sequence commonly avoided in Bantu languages (Kisseberth \& Odden 2003:67). The rule is formulated and exemplified in (30) and (31), respectively. Again, class 2a nouns are the only words where there are both prefix tones and stem tones.

(30) Stem Tone Deletion

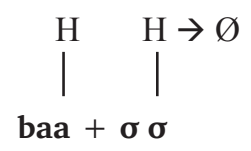

(31) Derivation

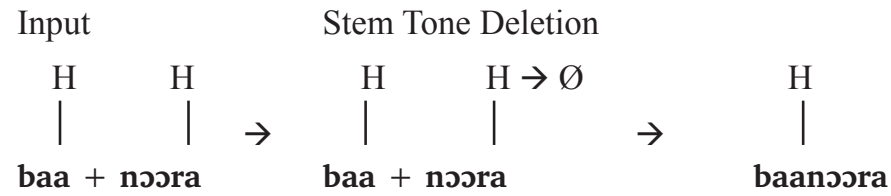

However, there are also instances where Plateauing takes place with class $2 \mathrm{a}$ prefix baá-. Compare example (32) below to example (26) above. The condition for Plateauing is that the stem tone is word-final. ${ }^{14}$ The tone of the following word

13. Since there are no lexical tones on verb stems, this is actually the only context found so far where two tones become adjacent within a word.

14. It is not clear from the present set of data if the condition for Plateauing also includes a word with an initial high tone following the noun or if Plateauing can apply regardless of what follows the noun. In the associative construction (see below), Plateauing occurs in phrase-final position. 
is downstepped..$^{15}$ The rules are formulated and exemplified in (33) to (35). This alternative realization of tones of some class 2 a nouns confirms that the motivation for the deletion of the second stem tone is disfavouring the $\mathrm{HØH}$ sequence.

$$
\begin{aligned}
& \text { baá-nəora báare } \sim \text { baá-n’́órá 'báare 'those agama lizards'16 } \\
& \text { baá-yima báare baá-yímá 'báare 'those mothers' }
\end{aligned}
$$

(33) Plateauing

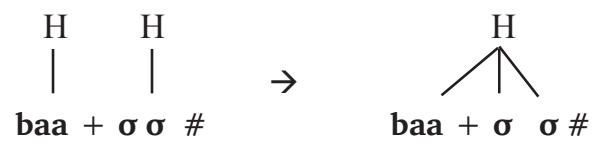

(34) Downstep<smiles></smiles>

(35) Derivation

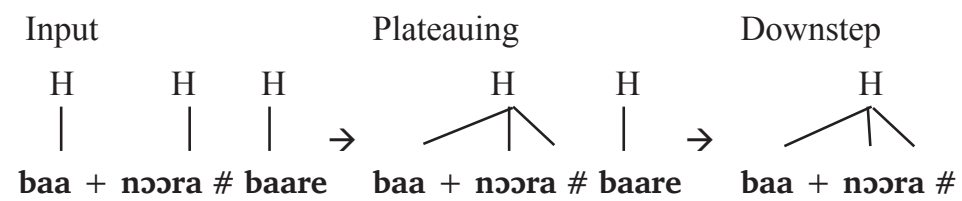<smiles>[10BH3-]</smiles>

OR

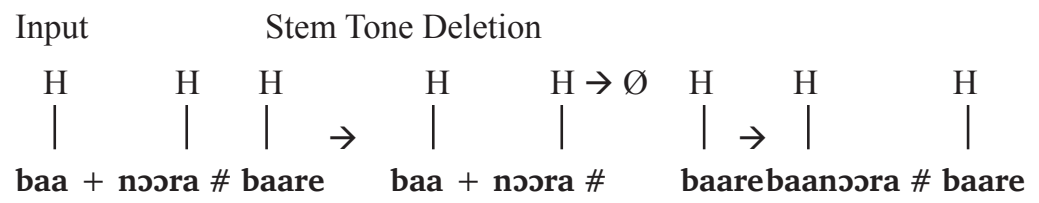

\section{Penultimate Spread and Downstep}

Since class $2 \mathrm{a}$ is the only nominal prefix in Ikoma that has a lexical tone, Stem Tone Deletion and Plateauing presented above are the only tonal rules that apply across morpheme boundaries in nouns. However, on the level of noun phrases there are other tonal processes that show tone-syntax interaction.

15. Downstep also applies on other word boundaries, see section 'Penultimate Spread and Downstep' below.

16. See section 'High Tone Insertions' below for the insertion of the tone of the demonstrative. 
The rule Downstep formulated above always applies when two high tones become adjacent across word boundaries, as exemplified in (36). When there are no tones on the preceding word or the tone is on the prepenultimate syllable (see below) or further away from the last syllable of the word, the lexical tones are not affected, as in (38). A similar downstep with two high tones surfacing in adjacent syllables - without evidence of a floating low tone - occurs, for example, in Shambaa (G23) and in the Marachi and Nyala dialects of Luyia (J30) (Odden 1982; Marlo 2007).

$\begin{array}{ll}\text { eki-barí } & \text { 'flower' } \\ \text { ekibarí 'kíire } & \text { 'that flower' } \\ \text { ege-gí } & \text { 'mud wasp' } \\ \text { egegí 'kíire } & \text { 'that mud wasp' }\end{array}$

(37) Derivation

Input
$\begin{aligned} & \text { omu-gabo } \\ & \text { umugabo úure } \\ & \text { eri-hóorere } \\ & \text { erihóorere ríire }\end{aligned}$
$\begin{aligned} & \text { 'that medicine man' } \\ & \text { 'hail' }\end{aligned}$

When the high tone of the stem is on the penultimate syllable, the tone spreads to the right to the final syllable of the stem, as in example (39). This spread applies when a word with a high tone on the initial syllable follows, as in (40). Thus HØH sequences are again avoided, but now across word boundaries. The rule is formulated in (41) and exemplified in (42). The initial high tone of the following word is downstepped.

$\begin{array}{ll}\text { aba-témi } & \text { 'kings' } \\ \text { abatémí 'báno } & \text { 'those kings' } \\ \text { eme-kéra } & \text { 'tails' } \\ \text { emekérá 'gíire } & \text { 'those tails' } \\ \text { a-híti } & \text { 'hyena' } \\ \text { ahítí 'íire } & \text { 'that hyena' }\end{array}$

\author{
ahíti erahúrumuka \\ a-híti e-ra-hurumuk-a \\ 9-hyena 9.SBJ-CONT-rush-FV \\ 'hyena rushed'
}

\section{ahítí 'hánó 'éhurumukiri ${ }^{17}$}

a-híti hano e-hurumuk-iri

9-hyena 16-DEM 9.SBJ-rush-ANT

'when hyena had rushed'

17. This example shows that Penultimate Spread applies to both the noun and the demonstrative, since both have a penultimate high and a high-initial word following. 
(41) Penultimate Spread

$$
\begin{array}{ccc}
H & \\
\sigma & \sigma \#
\end{array}
$$

(42) Derivation

$$
\underset{\text { abatemi bano }}{\text { Input }} \rightarrow \underset{\text { abatemi bano }}{\mathrm{H}} \rightarrow
$$

The Penultimate Spread also applies when the vowel of the penultimate syllable is long, both with long vowels resulting from compensatory vowel lengthening, as in (43), as well as with lexically long vowels, as in (44). This shows that Penultimate Spread counts syllables, not moras.

$$
\begin{array}{ll}
\text { eme-góndo } & \text { 'field' } \\
\text { emegóndó 'gíire } & \text { 'those fields' }
\end{array}
$$

$\begin{array}{ll}\text { emi-gáate } & \text { 'loaves of bread' } \\ \text { emigááté 'gíire } & \text { 'those loaves of bread' }\end{array}$

The Penultimate Spread can also take place when the noun is followed by a word without a high tone. In this context, spreading is optional, as shown in example (45). This optional spread is not shown in other examples in this article.

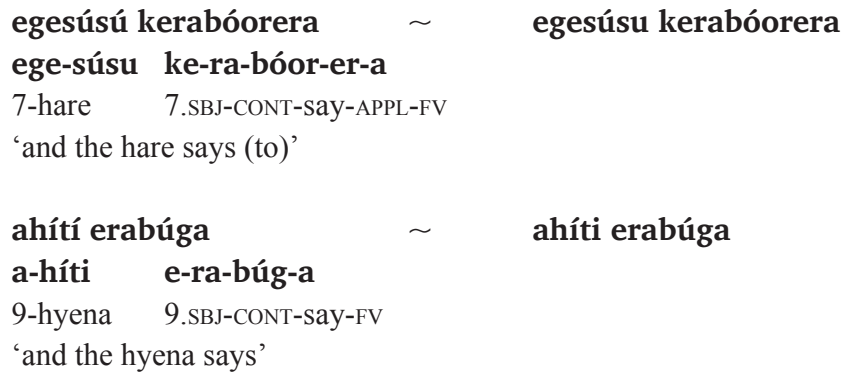

\section{Associative Construction}

The associative marker often carries a high tone. In the analysis below, this high tone is inserted as the first tonal rule of the associative, with certain restrictions, exemplified in detail below. ${ }^{18}$

18. Analysing the failure of the associative tone to be realized in some contexts as a failure of the tone to be inserted in the first place was pointed out by the anonymous reviewer. 
The shape of the associative is determined by the head noun only; the possible preprefix of the modifier noun is deleted and it does not affect the vowel of the associative. However, the consonant of the associative morpheme is affected by Dahl's Law (see, eg, class 15 associative ko in (46) below).

The tone of the associative marker is always realized when both of the nouns are toneless, regardless of the number of the stem syllables of the nouns, as in (46). The insertion of the associative tone is formulated in (47).

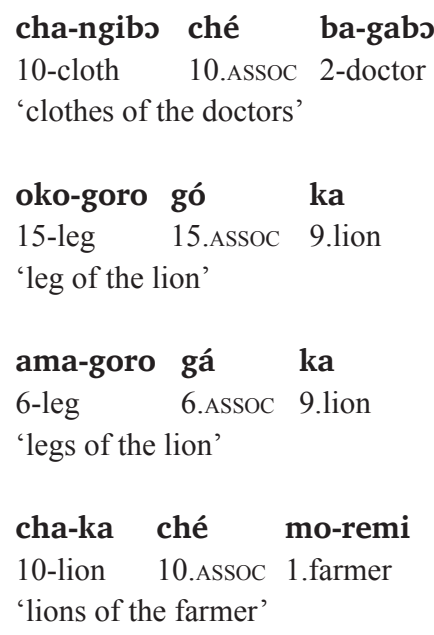

(47) $\mathrm{H}$ Insertion of the Associative (H Insertion)

$$
\begin{gathered}
\mathrm{H} \\
\sigma \\
\sigma \\
\mathrm{n}_{\text {[noun] }} \# \sigma_{[\text {Assoc] }} \# \sigma \mathrm{n}_{\text {[noun] }}
\end{gathered}
$$

In addition to the $\mathrm{CV}$-shape of the associative shown in the examples in this section, the associative marker consists of a vowel only in some noun classes, e.g. é in class 9. Without the intervening consonant, this vowel elides but the tone remains. This elision causes further tonal changes with the V-shaped associative, but these changes are not discussed in this paper.

The shape of the noun class prefix (i.e. $\mathrm{V}-\mathrm{CV} / \mathrm{CV}$ or $\mathrm{V}$ ) as well as the number of stem syllables of the modifier noun play a role in determining the surface realizations of the tones in associative construction, as will be shown below. All noun class prefixes, except class 2 a prefix baá- have the same underlying tonal form, i.e. they are all toneless.

When the head noun is toneless but the modifier noun has a stem tone, the tone of the associative is always realized if the modifier noun has a noun class prefix, as in (48). The place of the stem tone does not make any difference.

Another approach would be to link the associative marker with the tone in the underlying form and formulate rules that delete the tone in certain contexts. Further support for the analysis that inserts the associative tones comes from the closely related dialect Isenye in which the associative marker does not have a tone at all. 


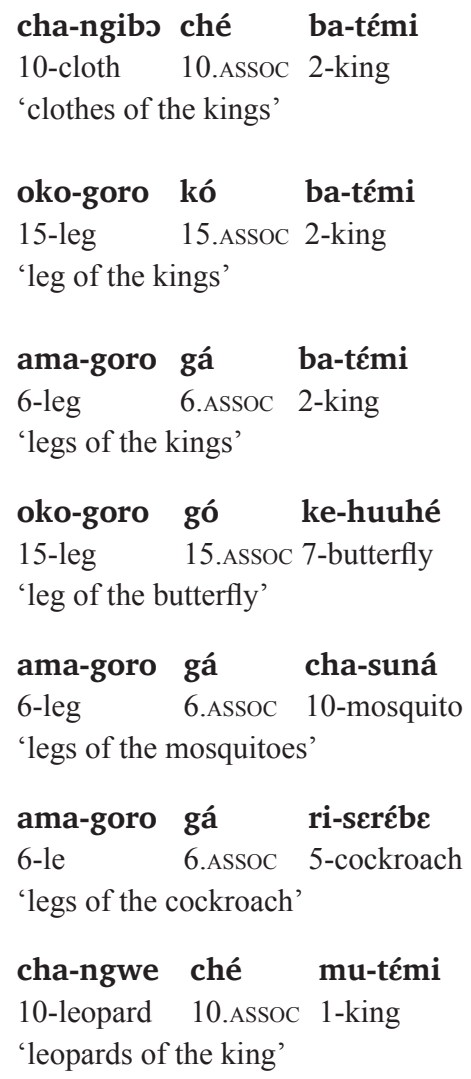

When the modifier noun does not have a noun class prefix, the tone of the associative is realized if the stem tone is not on the first syllable of the noun stem, i.e. adjacent to the tone of the associative (49). When the tone of the associative would become adjacent to the stem tone of the modifier noun the tone of the associative tone is not inserted (50). This condition for H Insertion is formulated in (51) and exemplified in $(52)$.

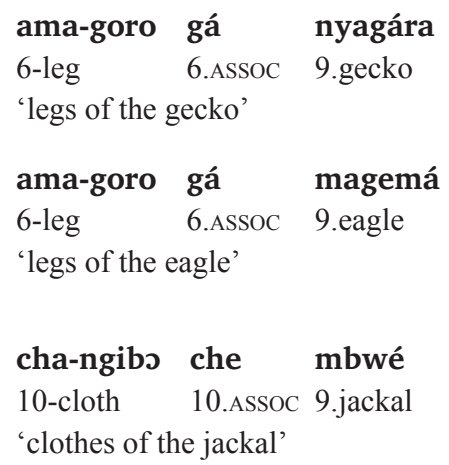




\begin{abstract}
aba-gabo ba mbóro
2-doctor 2.ASso 9.monitor.lizard

'doctors of the monitor lizard'
\end{abstract}

ama-goro ga mbérété

6-leg 6.ASSOC 9.goat

'legs of the goat'

(51) Condition on H Insertion

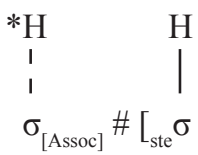

(52) Derivation

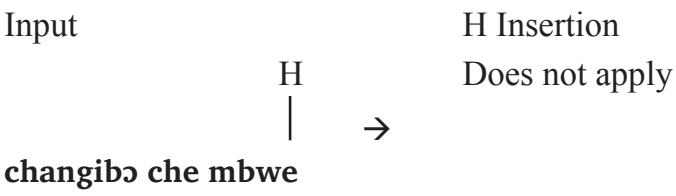

The tendency to avoid HØH sequences attested with class 2a prefix baá- (cf. section 'Tonal Changes in Classes 1a/2a' above) is also found in associative constructions. In the associative, the restriction only applies to phrase-final position where the underlyingly toneless penultimate syllable is realized with a high tone, as in (53), whereas, for example, in (49) above the same sequence is allowed phrase-medially.

$$
\begin{aligned}
& \text { cha-ngibo ché chá-mbwé } \\
& \text { 10-cloth 10.ASSOC } 10 \text {-jackal } \\
& \text { 'clothes of the jackals' } \\
& \text { ama-goro gá súná } \\
& \text { 6-leg 6.ASSOC 9.mosquito } \\
& \text { 'legs of the mosquito' } \\
& \text { ama-goro gá chá-mbérété } \\
& \text { 6-leg 6.ASSOC } \\
& \text { 'legs of the goats' }
\end{aligned}
$$

This tonal change is accounted for with Plateauing. As shown in the examples above, Plateauing takes place when there is a high tone on both sides of the penultimate syllable, be it the prefix syllable or the stem syllable. Note also that the same rule applies to the 'all H' stems where the multiply-linked tone functions as a single stem final tone and thus confirms the analysis of a multiply-linked high tone. The rule for Plateauing is reformulated in (54) from (33) above, and derivation is illustrated in (55) and (56). 
(54) Plateauing

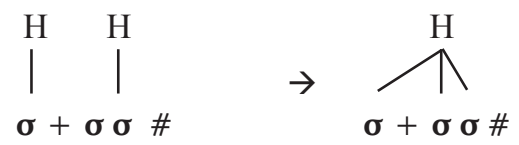

(55) Derivation

InputH

Insertion

Plateauing

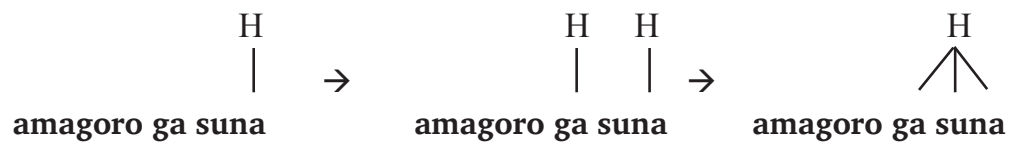

(56) Derivation

Input

H Insertion<smiles>C1CC1</smiles>

amagoro ga chamberete

amagoro ga chamberete

Plateauing<smiles>CCOOC[C@@H](C)C(C)C</smiles>

When the head noun has a stem-final high tone, the tone of the associative is downstepped, as in (57) and (58), in line with the examples in (36) above.

\begin{tabular}{|c|c|c|}
\hline eki-barí & 'ké & ngibo \\
\hline 7-flowe & 7.ASSOC & 9.cloth \\
\hline \multicolumn{3}{|c|}{ 'flower of the cloth' } \\
\hline ebi-barí & 'bé & ngibo \\
\hline 8-flower & 8.ASSOC & 9.cloth \\
\hline \multicolumn{3}{|c|}{ 'flowers of the cloth' } \\
\hline eme-kun & 'gé & cha-ngwe \\
\hline 4-navel & 4.ASSOC & 10.leopard \\
\hline
\end{tabular}

(58) Derivation

Input

H Insertion

Downstep

$\left.\right|_{\text {ekibari ke ngibs }} ^{\mathrm{H}} \rightarrow$

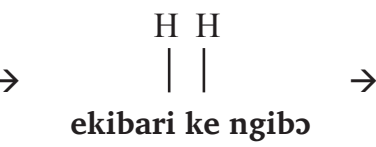

$\mathrm{H}$ !H ekibari ke ngibo 
When the head noun has a stem tone on the penultimate syllable, the tone is spread to the final syllable and the tone of the associative is downstepped, as in (59) with the derivation in (60). Again, this is analogous to the examples in (39) above.
aba-témí 'bá ka
2-king 2.ASSOC 9.lion
'kings of the lion'
aba-témí 'bá cha-ka
2-king 2.ASSOC 10-lion
'kings of the lions'
aba-témí 'bá nchera
2-king 2.ASSOC 9.road
'kings of the road'

(60) Derivation

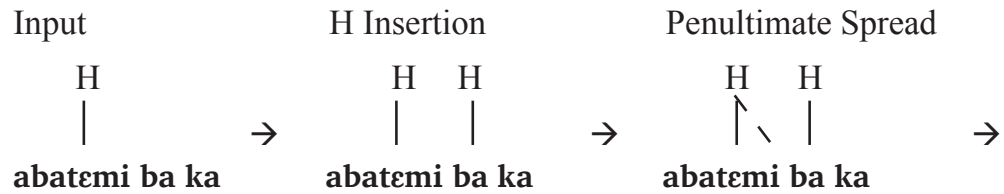

Downstep<smiles>C1CC1</smiles>

abatemi ba ka

When both nouns have a stem tone, the tone of the associative fails to be inserted, as in (61). The tones do not need to be adjacent to each other, and thus there is a condition on H Insertion: a maximum of two underlying high tones is allowed in the associative construction. The derivation is presented in (62).

$$
\begin{aligned}
& \begin{array}{l}
\text { ama-ráka ga cha-mémbe } \\
\text { 6-voice 6.ASSOC } \\
\text { 'voices of the bells' }
\end{array} \\
& \begin{array}{lll}
\text { ama-ráka ga } & \text { ke-huuhé } \\
\text { 6-voice } & \text { 6.ASSOC } & \text { 7-butterfly } \\
\text { 'voices of the butterfly' } & \\
\text { ebi-barí be } & \text { mo-té } \\
\text { 8-flower } \quad \text { 8.ASSOC } & \text { 3.tree } \\
\text { 'flowers of the tree' }
\end{array}
\end{aligned}
$$




\begin{tabular}{|c|c|c|}
\hline ama-bóko & ga & nyagára \\
\hline 6-arm & 6.ASSOC & 9.gecko \\
\hline \multicolumn{3}{|c|}{ 'arms of the gecko' } \\
\hline aba-témi & ba & híti \\
\hline 2-king & 2.ASSOC & 9.hyena \\
\hline \multicolumn{3}{|c|}{ 'kings of the hyena' } \\
\hline eme-té & ge & kúru \\
\hline 4-head & 4.ASSOC & 9.tortoise \\
\hline \multicolumn{3}{|c|}{ 'heads of the tortoise' } \\
\hline eme-kundé & ge & noวrá \\
\hline 4-head & 4.ASSOC & 1a.agama.lizard \\
\hline
\end{tabular}

(62) Derivation

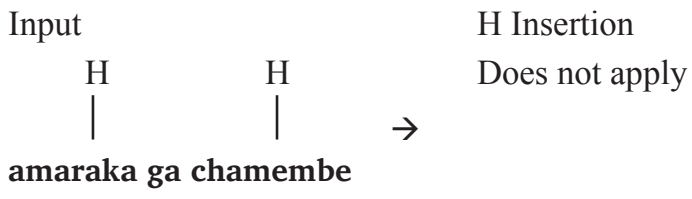

When the head noun has a stem-final tone and the modifier is a monosyllabic hightoned noun without a prefix, as in (63) and (64), a НØН sequence is formed at the end of the associative phrase, after H Insertion fails to apply. Since this sequence is not allowed phrase-finally, Plateauing takes place. If the tones were separate high tones, they would be subject to Downstep, but here the tones are realized as a level tone. Again, the rule also applies to the 'all H' stems, as in (65) and (66). When there are more than one syllable between the high tones, Plateauing does not apply, as in (67) and (68).

$$
\begin{aligned}
& \text { cha-suná ché mbwé }{ }^{19} \\
& \text { 10-mosquito 10.Assoc 9.jackal } \\
& \text { 'mosquitos of the jackal' } \\
& \text { eme-tú gé mbwé } \\
& \text { 4-head 4.Assoc 9.jackal } \\
& \text { 'heads of the jackal' } \\
& \text { cha-ndá ché mbwé } \\
& \text { 10-louse 10.Assoc 9.jackal } \\
& \text { 'lice of the jackal' }
\end{aligned}
$$

19. When the noun following the associative marker has an initial NC cluster, the vowel of the associative is lengthened (lengthening not marked in the examples). This shows again that when disfavouring the $\mathrm{HØH}$ sequence, syllables, not moras, are counted. 
(64) Derivation
Input
H Insertion
Plateauing

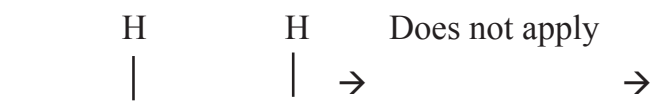
chasuna che mbwe

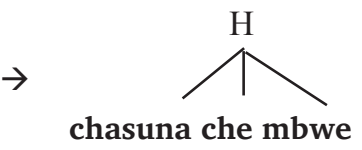

$(65)$

$\begin{array}{ll}\text { eme-kundé gé } & \text { nyábúúrí } \\ \begin{array}{l}\text { 4-navel } \\ \text { 'navels of the cow' }\end{array} & \end{array}$

(66) Derivation

Input

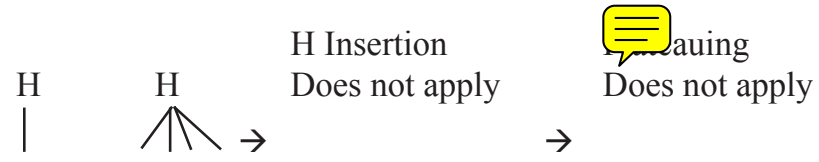

emekunde ge nyabuuri

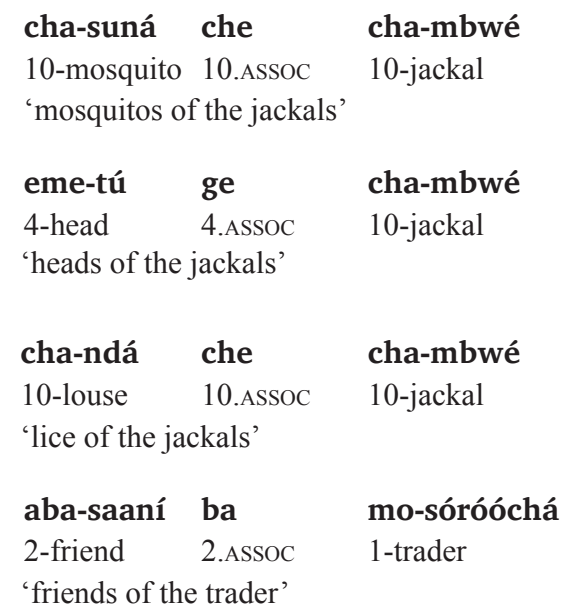

(68) Derivation

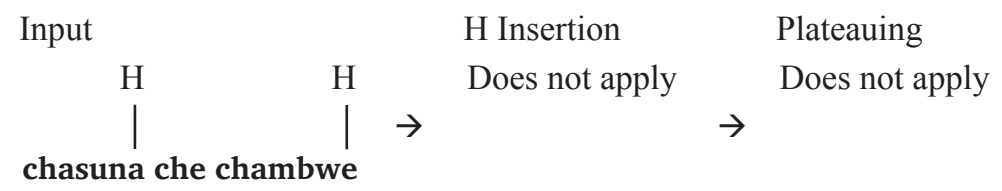

In some contexts, when the head noun has a penultimate high tone, an unexpected $\mathrm{H}$ insertion takes place, as in (69). In these examples, the modifier noun has a stemfinal high tone and either a stem syllable or a prefix syllable between the associative marker and the stem tone. Since both of the nouns have a stem high, one would expect the tone of the associative to fail to be inserted. Instead, the associative has a surface high tone and Plateauing applies to the final $\mathrm{HØH}$ sequence and the penultimate high of the head noun is spread and causes the level high tone (result 
of Plateauing) to be downstepped. This process is exemplified in (70). Without the intervening syllable between the associative and the stem tone of the modifier noun, the tone of the associative fails to be inserted (71). The tone of the associative is also not inserted if there is more than one syllable between the final syllable of the head noun with a penultimate high tone and the high-toned syllable of the modifier noun, as in (72).

$$
\begin{aligned}
& \text { aba-témí 'bá súná } \\
& \text { 2-king 2.AssoC 9.mosquito } \\
& \text { 'kings of the mosquito' } \\
& \text { aba-témí !bá mó-byá } \\
& \text { 2-king 2.Assoc 3-arrow } \\
& \text { 'kings of the arrow' } \\
& \text { aba-témí 'bá rí-hárárá } \\
& \text { 2-king 2.Assoc 5-grasshopper } \\
& \text { 'kings of the grasshopper' } \\
& \text { obo-óké 'bó mó-té } \\
& \text { 14-honey 14.Assoc 3-tree } \\
& \text { 'honey of the tree' }
\end{aligned}
$$

(70) Derivation

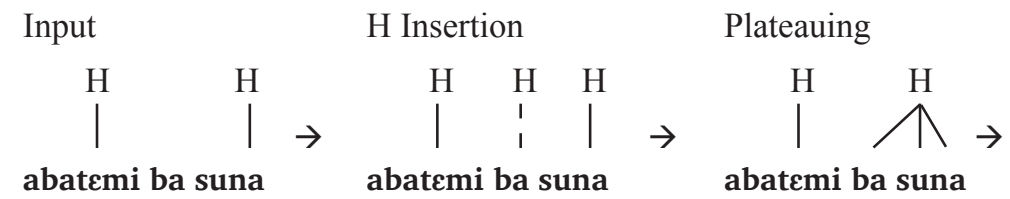

Penultimate Spread

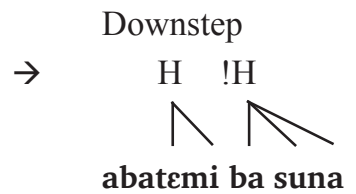<smiles>CCCC</smiles>

abatemi ba suna

$$
\begin{aligned}
& \text { aba-témi ba mbwé } \\
& \text { 2-king 2.ASSOC 9.jackal } \\
& \text { 'kings of the jackal' } \\
& \text { aba-témi ba ká } \\
& \text { 2-king 2.Assoc 9.house } \\
& \text { 'kings of the house' } \\
& \begin{array}{lll}
\text { ama-bóko } & \text { ga } & \text { mbérété } \\
\text { 6-arm } & \text { 6.ASSOC } & \text { 9.goat }
\end{array}
\end{aligned}
$$




$$
\begin{aligned}
& \text { aba-témi ba ri-sérebe } \\
& \text { 2-king 2.ASSOC 5-cockroach } \\
& \text { 'kings of the cockroach' }
\end{aligned}
$$

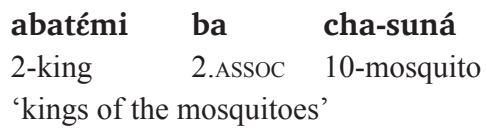

As seen in the derivation in (70) above, H Insertion applies in this context although both noun stems have a stem tone. If $\mathrm{H}$ Insertion failed to apply the condition for Plateauing would not be met and the result would be *abatémi ba suná.

Why then is the associative tone inserted in such phrases as in (69) above, but fails to be inserted in, for example, such phrases as ebi-barí be mo-té 'flowers of the tree' and eme-kundé ge noərá 'navels of the agama lizard' (in (61) above and (73) below)? The only difference between these and the examples in (69) is that the stem tone is on the final syllable of the head noun in the former, but on the penultimate syllable of the head noun in the latter. The adjacency with the stem tone could be the reason that blocks the application of $\mathrm{H}$ Insertion, but then such examples, as in (57) above, where the modifier noun does not have a high tone, would form an exception to this restriction.

(73) Derivation

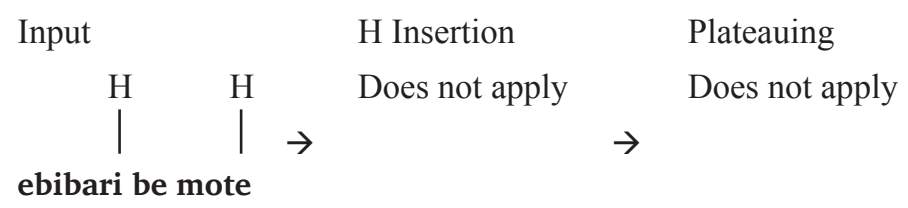

There seems to be more Plateauing taking place when the associative marker is only a vowel; these other contexts could possibly shed light on the now unexplained insertion of the associative tone. Also more complex associative phrases need to be investigated before the tonal changes can be fully understood.

Another type of phrase that functions tonally in the same way as the associative phrase is the na 'and, with' phrase: na is realized with a high tone, if both nouns conjoined with na do not have a stem tone (74). Unlike in the associative, the vowel

\begin{tabular}{|c|c|}
\hline $\begin{array}{l}\text { omu-gabs } \\
\text { 1-medicine.man } \\
\text { 'a medicine man }\end{array}$ & $\begin{array}{l}\text { nó-mo-remi } \\
\text { and-1-farmer } \\
\text { and a farmer' }\end{array}$ \\
\hline $\begin{array}{l}\text { omu-témí } \\
\text { 1-kin } \\
\text { 'a king }\end{array}$ & $\begin{array}{l}\text { 'nó-mu-gabo } \\
\text { and-1-medicine.man } \\
\text { and a medicine man' }\end{array}$ \\
\hline
\end{tabular}
of the conjunction is deleted when the following noun has a preprefix. 


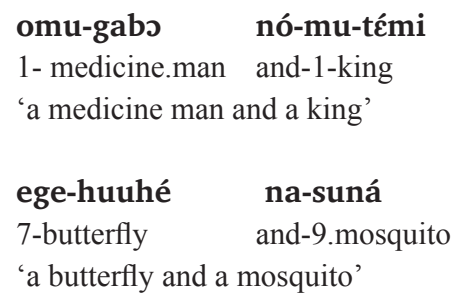

\section{High Tone Insertions}

In addition to the $\mathrm{H}$ Insertion rule of the associative construction, there are other contexts where tones are inserted in Ikoma tonology. Only the most common contexts are discussed here, while the overall range and restrictions of these rules remains a topic for further research.

Demonstrative pronouns (-no, -yo, and -Vre; prefixed with the concord prefix) have an initial high tone on the surface when the pronoun is not in utterance-initial position, regardless of the syntactic function of the preceding word. This high tone could be inserted, or the demonstratives have a lexical tone which is deleted in utterance-initial position. In analogy with the analysis of some closely related languages, the tone of the demonstratives is analyzed here as inserted rather than lexical (cf. High Tone Insertion in Jita and other Lacustrine Bantu languages in Downing 1996). This insertion seems to apply only to demonstrative pronouns and not to, for example, adjectives and numerals, whereas in Jita it also applies to other modifiers (Downing 1996:79). ${ }^{20}$ The tonal variation between the initial and non-initial context is exemplified in (75) to (77) and the rule is formulated and exemplified in (78) and (79).

$$
\begin{aligned}
& \text { Hayo káare ... } \\
& \text { ha-yo káare } \\
& \text { 16-DEM long.ago } \\
& \text { 'Long ago ...' }
\end{aligned}
$$

$$
\begin{aligned}
& \text { Uyo aráagi ... } \\
& \text { u-yo a-ráa-gi } \\
& \text { 1-DEM 1.SBJ-COND-go } \\
& \text { 'When that [person] goes ...' }
\end{aligned}
$$

\section{Erigano rerasírera háyo.}

$$
\begin{aligned}
& \text { eri-gano re-ra-sir-er-a ha-yo } \\
& \text { 5-tale 5.SBJ-CONT-end-APPL-FV 16-DEM } \\
& \text { 'The tale ends here.' }
\end{aligned}
$$

$\begin{array}{ll}\text { omuúké !wáache úyo } & \\ \text { omu-úke w-aache } & \text { u-yo } \\ \text { 1-daughter 1-1PS.POSS } & \text { 1-DEM } \\ \text { 'that daughter of his/her' } & \end{array}$

$$
\begin{aligned}
& \text { omoótó !úure } \\
& \text { omo-óto u-Vre } \\
& \text { 1-person 1-DEM } \\
& \text { 'that person' }
\end{aligned}
$$

20. The same possibly also applies to Ikoma possessives, as in example (76), but more data is needed on these. 
(78) Initial H Insertion of Demonstratives (H Insertion 2)

$$
\begin{gathered}
H \\
1 \\
\boldsymbol{\sigma} \# \boldsymbol{\sigma} \boldsymbol{\sigma}_{[\mathrm{Dem}]}
\end{gathered}
$$

(79) Derivation

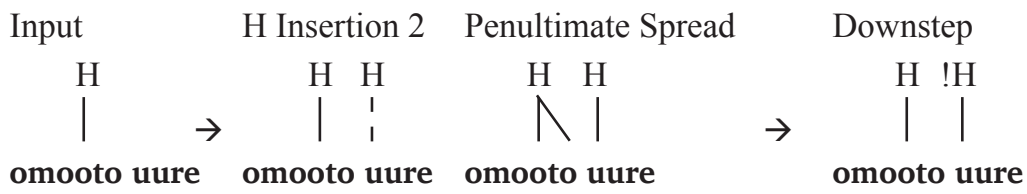

Another type of $\mathrm{H}$ insertion takes place when two toneless words occur adjacent to each other. The full scope of this insertion is yet to be investigated, since the grammatical tone also needs to be taken into account here, but one common target context for this rule is a toneless noun that follows any toneless verb. ${ }^{21}$ In this context, a high tone is inserted to the initial syllable of the following noun, i.e. to the preprefix or to the prefix, as in (80) and (81) with the anterior and (82) with the imperative. There is no tone insertion when the verb has a grammatical tone; compare the past forms in (83) to the anterior forms in (80). Also, when the noun has a stem tone, there is no tone insertion; compare example (84) to example (81) and example (85) to example (82). The rule is formulated and exemplified in (86) and (87).

Ntotukiri rí-riba. n-to-tuk-iri eri-riba VI-1 PP.SBJ-dig-ANT 5-hole

'We have dug a hole.'
Mbagoriri chángibo.

n-ba-gor-iri cha-ngibo

VI-2.SBJ-buy-ANT 10-cloth

'They have bought clothes.'

(81) Nagabwine ámashere íyo.

$\begin{array}{lll}\text { n-a-ga-bwine } & \text { ama-shere } & \text { i-yo } \\ \text { VI-1.SBJ-6.OBJ-see.ANT } & \text { 6-hoe } & \text { 9-DEM }\end{array}$

$$
\begin{aligned}
& \text { Tuka rí-riba! } \\
& \text { tuk-a eri-riba } \\
& \text { dig-FV 5-hole } \\
& \text { 'Dig a hole!' }
\end{aligned}
$$

\author{
Otatuka rí-riba! \\ o-ta-tuk-a eri-riba \\ 2PS.SBJ-NEG-dig-FV 5-hole \\ 'Do not dig a hole!'
}

21. For example, when a toneless verb follows a toneless demonstrative, the verb is realized with an initial high tone, as in bahikiri 'they have arrived' vs. hano báhikiri 'when they had arrived'. However, in verbal tonology there are also quite a few other contexts where tones are inserted.

Poletto (1998) describes in detail a H insertion rule in Runyankore (EJ13). In this Ugandian language, the target of HIns is a toneless word preceded by another toneless word within the same phrase. HIns is only restricted by syntactic factors, e.g. adjectives cannot be followed by a toneless word within the same phrase (Poletto 1998:262). 


$\begin{array}{lll}\text { Ntootúkiri ri-riba. } & & \text { Mbaagóriri changibo. } \\ \text { n-to-V-tuk-iri } & \text { ri-riba } & \text { n-ba-V-gor-iri cha-ngibo } \\ \text { VI-1PP.SBJ-PST-dig-ANT } & \text { 5-hole } & \text { VI-2.SBJ-PST-buy-ANT 10-cloth } \\ \text { 'We dug a hole.' 'They bought clothes.' }\end{array}$

Nakebwine ege-túmbe íyo.
n-a-ke-bwine ege-túmbe i-yo
VI-1.SBJ-7.OBJ-see.ANT 7 -chair
'He has found the chairs there,

Tuka chanúmbu!

tuk-a cha-númbu

dig-FV 10-potato

'Dig potatoes!'
Otatuka chanúmbu! o-ta-tuk-a cha-númbu

2PS.SBJ-NEG-dig-FV 10-potato

'Do not dig potatoes!'

(86) H Insertion 3 (Condition: both words are toneless)

$$
\begin{array}{r}
H \\
1 \\
1 \\
\sigma \# \boldsymbol{\sigma}
\end{array}
$$

(87) Derivation

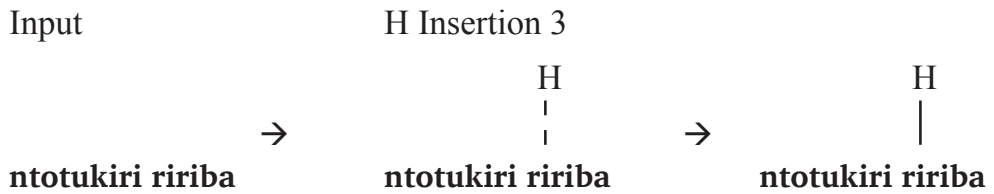

Interestingly enough, in the closely related Nata dialect, the toneless noun stems seem to have a $\mathrm{H}$ on the prefix also when a word with a high tone precedes. Thus Nata resembles Zinza, where there is a $\mathrm{H}$ tone on the preprefix, but it is only realized when the initial vowel coalesces with the preceding syllable (Kisseberth \& Odden 2003:61). Also, in Proto-Bantu the preprefix was apparently H (Kisseberth \& Odden 2003:60). With this in mind, the insertions presented in this section could also be analyzed as lexical tones that are deleted in some contexts, but a more comprehensive description calls for more research and data on Ikoma and the neighbouring varieties.

\section{Conclusions}

The Ikoma nominal tone system is more tonal than the Lacustrine Bantu languages typically are. Instead of employing the system of assigning a high tone on one or none of the stem syllables, Ikoma also has a pattern of a multiply linked high ('all $\left.\mathrm{H}^{\prime}\right)$. This is all the more interesting when compared to Isenye which is listed under the same code with Ikoma: Isenye seems to have only two tonal classes of bisyllabic noun stems, and these two classes do not match systematically to the three tonal 
classes of bisyllabic noun stems of Ikoma. Nata seems to be closer to Ikoma, both tonally and segmentally.

Of the geographically closest neighbouring languages, Kuria has reportedly lost most of the lexical contrast on nouns: the only tonal contrast in bisyllabic noun stems is whether the final vowel is $\mathrm{H}$ or $\mathrm{L}$ while the initial syllable is always H (Cammenga 2004). Ngoreme (E401) seems to have at least two tonal groups in bisyllabic nouns (SIL 2009c). In Ikizu (E402) and Zanaki (E44), there is no lexical or grammatical tone attested (SIL 2009a, 2009d).

This paper is an initial description of the nominal tone system in Ikoma. Further research is needed before a comprehensive description of the system can be presented. However, this paper outlines the basic system and rules of the nominal tones and shows that the nominal tone system is still vital in Ikoma.

\section{Abbreviations}

$\begin{array}{llll}\text { ANT } & \text { anterior } & \text { OBJ } & \text { object } \\ \text { APPL } & \text { applicative } & \text { POSS } & \text { possessive } \\ \text { ASSOC } & \text { associative marker } & \text { PP } & \text { person plural } \\ \text { COND } & \text { conditional } & \text { PRS } & \text { present } \\ \text { CONT } & \text { continuous } & \text { PS } & \text { person singular } \\ \text { DEM } & \text { demonstrative } & \text { PST } & \text { past } \\ \text { FV } & \text { final vowel } & \text { SBJ } & \text { subject marker } \\ \text { N } & \text { nasal } & \text { V } & \text { vowel } \\ \text { NEG } & \text { negation } & \text { VI } & \text { verbal initial } \\ & & & \text { numbers refer to noun classes }\end{array}$

\section{Acknowledgements}

The data for this paper was collected in June-August 2008 and January 2010 in Musoma town and in some Ikoma villages near Mugumu. The main body of the data presented in this paper comes from Mr. Mussa Karume Tobias and Mr. Paul Muya to whom I wish to extend my warmest thanks. I am also grateful to the SIL for fruitful co-operation, especially to Holly Higgins and Oliver Stegen for introducing me to the Ikoma language and sharing with me their knowledge of the language. I thank the Emil Aaltonen Foundation and the Finnish Cultural Foundation for making the fieldwork possible.

\section{References}

Cammenga, Jelle. 2004. Igikuria Phonology and Morphology. (East African Languages and Dialects 15) Cologne: Rüdiger Köppe Verlag.

Doke, C.M. \& S.M. Mofokeng. 1957. Textbook of Southern Sotho grammar. Cape Town: Longman. 
Downing, Laura J. 1996. The Tonal Phonology of Jita. (LINCOM Studies in African Linguistics 05) München: LINCOM.

Harjula, Lotta. 2004. The Ha Language of Tanzania: Grammar, Texts and Vocabulary. Köln: Rüdiger Köppe Verlag.

Hyman, Larry. 2001. 'Privative tone in Bantu'. In Shigeki Kaji (ed.), Crosslinguistic studies of tonal phenomena, 237-257. Tokyo: ILCAA.

Hyman, Larry M. \& Charles W. Kisseberth, eds. 1998. Theoretical Aspects of Bantu Tone. (CSLI Lecture Notes 82) Stanford: CSLI Publications.

Kisseberth, Charles and David Odden. 2003. 'Tone'. In Nurse \& Philippson (eds), The Bantu Languages, 59-70.

Maho, Jouni. 2003. 'A classification of the Bantu languages: an update of Guthrie's referential system'. In Nurse \& Philippson (eds), The Bantu Languages, 639-651.

Marlo, Michael R. 2007. A verbal tonology of Lunyala and Lumarachi: two dialects of Luluyia (Bantu, J.30, Kenya). PhD Dissertation, University of Michigan.

Muzale, Henry R.T. \& Josephat M. Rugemalira. 2008. 'Researching and Documenting the Languages of Tanzania', Language Documentation \& Conservation 2(1):68-108.

Nurse, Derek \& Gérard Philippson, eds. 2003. The Bantu Languages. London \& New York: Routledge.

Odden, David. 1982. 'Tonal Phenomena in Kishambaa'. Studies in African Linguistics, 13(2):177-208.

- 1989. 'Predictable tone systems in Bantu'. In Harry van der Hulst \& Norval Smith (eds), Autosegmental studies on pitch accent systems, 225-251. Dordrecht: Foris.

Philippson, Gérard. 1998. 'Tone Reduction vs. Metrical Attraction in the Evolution of Eastern Bantu Tone Systems'. In Hyman \& Kisseberth (eds), Theoretical Aspects of Bantu Tone, 315-329.

Poletto, Robert E. 1998. Topics in Runyankore Phonology. PhD Dissertation. The Ohio State University.

SIL International, Uganda-Tanzania Branch [SIL] 2009a. Ikizu Orthography Sketch. Unpublished manuscript. Musoma: SIL International.

— 2009b. Ikoma Orthography Sketch. Unpublished manuscript. Musoma: SIL International.

— 2009c. Ngoreme Orthography Sketch. Unpublished manuscript. Musoma: SIL International.

— 2009d. Zanaki Orthography Sketch. Unpublished manuscript. Musoma: SIL International.

\section{Author's address}

Lotta AuNIO 


\section{Résumé}

L'ikoma est une langue bantu lacustre parlée dans le district de Serengeti, dans la région de Mara (Tanzanie occidentale) référencée $\mathrm{E}(\mathrm{J}) 45$ dans la classification de Guthrie (mise à jour par Maho). L'ikoma fait usage à la fois de tons lexicaux et grammaticaux. Mais les constructions nominales sont les seules qui manifestent des contrastes tonals. Ces constructions et les règles tonales qui s'y appliquent sont traitées dans cet article. Nous montrerons que la tonologie nominale de l'ikoma est plus complexe que celle typique des systèmes tonals restreints que l'on rencontre dans d'autres langues bantu de cette région. 